\title{
Recent Acquisitions
}

AUDUBON, JOHN JAMES. Twenty of the 435 plates in Audubon's clouble elephant folio, including the passenger pigeon and the snowy owl, but not the American turkey, are beautifully reproduced, in full size, in The Birds of America: A Selection of Plates Facsimile (1972), printed in Dresden, Germany, in collaboration with the Ariel Press, London.

BASKIN, LEONARD. Shakespeare's Titus Andronicus, with etchings and wood engravings by Leonard Baskin (1973), is the first volume of the Gehenna Press Shakespeare. It joins, in our holdings, other works by Baskin, such as his lecture on book illustration, To Colour Thought (1967), which is one of 300 copies printed at the Officina Bodoni in Verona.

BLAKE, WILLIAM. The Trianon Press facsimile, in three folio volumes (1972), of William Blake's impressive Water-Colour Designs for the Poems of Thomas Gray. Commissioned by John Flaxman in 1797, and later owned by William Beckford of Fonthill Abbey, the original watercolors of these 116 designs remained in obscurity until their exhibition by the Tate Gallery in 1971 and their subsequent reproduction in this handsome edition printed in Paris.

BLESSINGTON, MARGUERITE, COUNTESS OF. Twentythree letters addressed to this nine- teenth-century lady of literature and fashion, and friend of Lord Byron. Among her present correspondents are Frederick Marryat, Bulwer-Lytton, B. W. Procter, George Sand, and David Wilkie.

BLUNDEN, EDMUND. Eighteen autograph letters or cards addressed to such various correspondents as Miss E. D. Bangay, Cyril W. Beaumont, John Collier, Arthur Miller, Nelson Taylor, and Margaret Stanley-Wrench.

CALHOUN, MARY. Preliminary notes and four successive drafts of Magic in the Alley (1970), by a well-known children's author who has remarked that "in the story I was thinking of the alleys of Keokuk, Iowa, in fantasy." Gift of Mary Calhoun to the Iowa Authors Collection.

CUMMINGTON PRESS. Two of the last books to be printed by the Cummington Press at West Branch, Iowa, are The Meeting Place of Colors (1972), poems by Barbara Gibbs with four plates from drawings by Ulfert Wilke, and Lines (1972), fifteen poems by S. J. Marks with four drawings by Elizabeth Osborne. This latter volume carries an Omaha, Nebraska, imprint, and from this new location of the press has recently come Gerald Stern's The Naming of Beasts and Other Poems (1973) in an edition of one hundred copies. 
DEAD SEA SCROLLS. Color photographs, taken in 1948, of "The Great Isaiah Scroll," "The Order of the Community," and "The Pesher to Habakkuk" are presented in this edition of Scrolls from Qumran Cave I (1972). These important manuscripts, comprising Biblical texts, a history of the Essenes, and exegetical lore, were discovered in the Judean desert a quarter of a century ago.

DESCARTES, RENE. Les principes de la philosophie (1698) and Opera Omnia (1713) are both rare collections of Descartes' philosophical works. The latter, printed in Amsterdam in nine volumes, appears to be an edition "made up" by the publisher from existing editions of the individual works. Gift of John Martin, M.D.

DOVES PRESS. At the opposite pole from the ornateness of the Kelmscott Press is the simplicity of the Doves Press. Faust; eine Tragoedie von Goethe (1906) now joins on our shelves seventeen other publications from the press of $\mathrm{T}$. J. Cobden-Sanderson and Emery Walker.

DURER, ALBRECHT. The first edition in Italian of his classic work on the proportions of the human body, Della Simmetria de $i$ corpi humani (1591). Gift of John Martin, M.D.

EDWARDS, JONATHAN. His A Careful and Strict Enquiry into the Modern Prevailing Notions of that Freedom of Will, which is Supposed to be Essential to Moral Agency, Vertue and Vice, Reward and Punishment, Praise and Blame (1754) may have cast long shadows into the works of such later American authors as Hawthorne and Melville.
ERASMUS, DESIDERIUS. Two works printed in Leyden: the first Elsevier edition of the collected Colloquia (1636), and a French translation of The Praise of Folly (1713) with numerous illustrations after the younger Hans Holbein. Gift of John Martin, M.D.

GUTENBERG BIBLE. An original leaf from this most famous of books (ca. 1450-1455), being portions of chapters 9 and 10 from the Book of Judges. An imperfect copy of the book was acquired in 1921 by Gabriel Wells, who had single leaves bound in separate folio volumes with an introduction by $\mathrm{A}$. Edward Newton. Acquired through an exchange of duplicates.

HALL, JAMES NORMAN. Tivo letters, both written in 1934 to a Grinnell College classmate and his wife, Mr. and Mrs. James E. Stronks, one addressed from Tahiti and one from Colfax, Iowa. Gift to the Iowa Authors Collection from Mr. James E. Stronks.

HERBST, JOSEPHINE. Two two-page letters from this Iowa author, dating from the year 1939, one from Havana concerning an unsuccessful effort to get Ernest Hemingway to review her book Rope of Gold, and one from Santiago, Chile, discussing the decline of literary taste.

HOUGH, EMERSON. Fifty-two letters, 1903-1912, from Hough to Conrad Goeth, concerning Hough's interest in a farm near San Antonio, Texas. These letters relate to the project described by Hough in his article in the February, 1909, issue of Outing magazine.

HUNT, LEIGH. Seven autograph letters to William Courthope, A. B. R. Grosart, William Jerdan, B. Webster, J. G. de Wilde and 
others, and a draft of a letter concerning Richard Hengist Horne, with corrections by Leigh Hunt. Also two books once owned by Leigh Hunt: a copy of Scaliger's Poetices libri septem (1594), with a holograph indication that Hunt had purchased this book in Florence; and Hunt's copy of Griffith Hughes' The Natural History of Barbados (1750) with Hunt's signature on the title page. Hunt's father, Isaac Hunt, was a native of Barbados and a loyalist who escaped from Philadelphia in 1775 after being threatened with tar and feathers.

JOHNSON, SAMUEL. A second edition, in two small volumes, of The Prince of Abissinia (1759), his pseudo-Oriental tale of Rasselas, who escapes from a happy valley into the real world, only to find that "Human life is everywhere a state, in which much is to be endured, and little to be enjoyed." Together with a copy of Johnson's Prayers and Meditations (1785), published the year after his death.

LAWRENCE, D. H. Number 134 of a limited, signed edition of 200 copies of The Story of Doctor Manente, translated by Lawrence from the Italian of Grazzini and published in Florence in 1929.

LECHLITNER, RUTH. Typescripts, with holograph corrections, of two plays in verse, The Rising Wing (1938) and The Tree of Life (1958), together with papers relating to four collections of published poems: Tomorrow's Phoenix (Alcestis Press, 1937), Only the Years (Press of James A. Decker, 1944), The Shadow on the Hour (The Prairie Press, 1956), and A Changing Season (Branden Press, 1973). Gift of Ruth Lechlitner Corey.
MABBOTT COLLECTION. Although it centers on Edgar Allan Poe, the Mabbott Collection also includes works by certain of Poe's contemporaries, particularly American magazine editors of the second quarter of the nineteenth century. Fanny (1819), a satire, is FitzGreen Halleck's longest poem, and Norman Leslie (1835) is Theodore S. Fay's first novel, a best seller until it was excoriated by Poe in a review which became a greater sensation than the novel it reviewed. Purchased on the Mabbott Fund.

MAY, CHARLES PAUL. Several preliminary versions of his children's book Stranger in the Storm (1972), which developed from a short story published more than twenty years earlier. Its locale is the town of Salem, Iowa, shortly before the Civil War, and the story concerns the underground railroad and a runaway slave. Gift of Charles Paul May to the lowa Authors Collection.

MITFORD, MARY RUSSELL. Seven letters to Benjamin R. Haydon concerning visits, manuscripts. letters, and paintings, with an annotation by Haydon to the effect that his picture of Christ satisfied only Mrs. Siddons, Sir Walter Scott, William Wordsworth, and David Wilkie.

MURDOCH, IRIS. Uncorrected proof copy of her novel A Fairly Honourable Defeat (1970); six holograph notebooks comprising a portion of the original manuscript of the early novel Flight from the Enchanter (1956); five notebooks comprising two drafts of a play, The Servants and the Snow (produced at Greenwich in 1971), and four notebooks comprising three 
drafts of the dramatized version of The Italian Girl (1968).

PLINY THE ELDER. Two early sixteenth-century editions of Pliny's Natural History: an edition printed in Venice in 1519-1520 containing the extensive index by Joannes Camers, and an edition printed by Froben in 1530. Pliny died during the eruption of Vesuvius which buried Pompeii and Herculaneum in A.D. 79. Gift of John Martin, M.D.

PRAIRIE PRESS. Two volumes by the late August Derleth, Walden Pond (1968) and Caitlin (1969), both with wood engravings by Frank Utpatel; and Selected Poems (1973) by E. L. Mayo, designed, printed, and bound by Carroll Coleman at The Prairie Press in Iowa City, Iowa.

RAGNAROK PRESS. Previously unpublished poems by Rochelle Holt appear in a slim volume, The Bare Tissue of Her Soul (1972), which bears the imprint of Folder Editions of New York; and poems by twelve women poets make up the volume Children of the Moon (1973), edited by Rochelle Holt and printed at the Ragnarok Press in Sioux City, Iowa.

ROXBURGHE CLUB PUBLICATIONS. The Roxburghe Club dates back to the year 1812 , when eighteen bibliophiles gathered at a London tavern to celebrate the record price of $£ 2260$ brought by the sale of the Duke of Roxburghe's copy of the Valdarfer Boccaccio. During the subsequent 162 years, the club members have published, in very limited editions, more than 230 books, many of them making available previously unpublished texts. The University of Iowa Libraries presently own 179 of the
Roxburghe Club publications, the most recent additions being the Correspondence of Sir Henry Unton, 1591-2 (1847), De Guileville's Le Pelerinage de Vie Humaine (1893), and Sir John Vanbrugh's Architectural Drawings in the Library of Elton Hall (1964).

SITWELL, EDITH. Nine letters, 1943-1953, to John Lehmann, and one, 1929, to Frederick Willis, now join our earlier collection of more than 100 letters from Dame Edith Sitwell.

STONE WALL PRESS. Paul Nelson's Cargo (1972) is a collection of poems published jointly by the Stone Wall Press and the Seamark Press in an edition of 250 copies; and Michael Van Walleghen's The Wichita Poems (1973), with prints by William Kough, is a recent issue carrying the Stone Wall Press imprint, also one of 250 copies.

TARGETS. Complete run of this little poetry magazine which was published at Sandia Park, New Mexico, between 1959 and 1963, supplemented by the editor's archive of manuscripts and correspondence. Among the poets represented are Marvin Bell, Charles Bukowski, Judson Crews, David Cornel DeJong, and many others. Gift of W. Lee Garner.

TORCH PRESS. Of the nine recently-acquired books printed at the Torch Press in Cedar Rapids, Iowa, the most notable is Vincent Starrett's The Unique Hamlet (1920). This copy, which has a signed inscription from the author to Meredith Janvier, with Starrett's "Sherlock Holmes" bookplate, is a gift from the late L. O. Cheever. And interesting as an association item, though it is not itself a 
Torch Press publication, is Captain Jack Crawford's Whar' the Hand o' God is Seen (1913). Inserted in this copy is a typescript poem signed by Captain Jack, which is addressed to Luther Brewer, the founder of the Torch Press.

VALE PRESS. Four books designed by Charles Ricketts and printed under his supervision: the Rowley Poems of Thomas Chatterton in two volumes (1898), the lyric Poems of Alfred Lord Tennyson (1900), Poems by William Wordsworth, selected by T. Sturge Moore (1902), and Danaë, a poem by T. Sturge Moore (1903).

WILSON, ANGUS. A proof copy of Anglo-Saxon Attitudes (1956) with corrections in the text bearing the initials R. S. (Roger Senhouse?) and A. W.

WINDHOVER PRESS. John Hoole's account of the last days of Samuel Johnson is first published in its entirety in the Windhover Press's Journal Narrative Relative to Doctor Johnson's Last Illness Three Weeks Before His Death (1972), edited with a preface by O M Brack, Jr. Also from the Windhover Press in Iowa City has come a translation, by F. W. Bornhauser, of Ronsard's Hercule Chrestien (1972), with an Afterword by Oliver Steele. 